\title{
Changes in the isoenzyme and kinetoplast DNA patterns of Trypanosoma cruzi strains induced by maintenance in mice
}

\author{
Mariângela Carneiro ${ }^{1}$, E.Chiari ${ }^{1}$, A.M.Gonçalves ${ }^{2}$, A.A. da Silva \\ Pereira $^{1}$, C.M. Morel ${ }^{2}$ and A.J. Romanha ${ }^{3}$ \\ ${ }^{1}$ Departamento de Parasitologia e de Bioquimica, ICB-UFMG, Belo Horizonte, Brazil, ${ }^{2}$ Departamento de \\ Bioquimica e Biologia Molecular, IOC.FIOCRUZ, Rio de Janeiro, Brazil, and ${ }^{3}$ Centro de Pesquisas \\ René Rachou, FIOCRUZ, Belo Horizonte, Brazil
}

(Received 31 October 1988; revised version received 22 May 1989; accepted 31 May 1989)

\begin{abstract}
Culture forms of thirteen Trypanosoma cruzi strains from 4 zymodemes and 9 schizodemes were inoculated and kept by successive passages in $\mathrm{C} 3 \mathrm{H}$ mice. The strains were initially from the following zymodemes: 3 from A, 3 from B, 4 from $C$ and 2 from $D$ and 1 from $A B$ mixed zymodemes. After approximately 18 months maintenance the parasites were isolated by hemoculture and again typed according to their isoenzyme and kinetoplast DNA patterns. The zymodeme A strains kept their initial patterns; from the 3 zymodeme B strains, two kept the initial patterns and one changed to zymodeme A; from the 4 zymodeme $C$, two kept the initial pattern and two changed to zymodeme $B$; from the 2 zymodeme $D$ strains, one kept the initial pattern and one changed to zymodeme $A$. The strain from AB mixed zymodeme was reduced to zymodeme A. The zymodeme changes were accompanied by schizodeme changes. Although not simultaneously, in one $T$. cruzi strain the parasitemia change was followed by zymodeme and schizodeme changes. The results showed that prolonged maintenance of $T$. cruzi in mice by successive passages alters the isoenzyme and k-DNA patterns of some strains and that these alterations tend to move towards zymodeme A, suggesting a selective effect of mice over these T. cruzi populations.
\end{abstract}

Key words: Trypanosoma cruzi; Zymodeme; Schizodeme.

\section{Introduction}

Intraspecific variations in $T . c r u z i$ strains have long been observed based on their behaviour in vertebrate and invertebrate hosts as well as in culture (Brener, 1977, 1985). Characterization in such models is, however, strongly influenced by a number of extrinsic factors and therefore the biological methods of characterization available have proven to be insufficient to detect parasite variation. On the other hand, biochemical methods have been successfully introduced for the intrinsic characterization of parasites. Among these methods, isoenzyme and kinetoplast DNA (k-DNA) patterns have been much used (Miles et al., 1980, 1981; Romanha et al., 1979a,b; Morel et al., 1980; Gonçalves et al., 1984b; Tibayrenc and Ayala, 1988). Using

Correspondence address: M. Carneiro, Departamento de Parasitologia, ICB-UFMG, Av. Antonio Carlos, 6627, C.P. 2486, 30161 Belo Horizonte, MG, Brazil 
isoenzyme patterns Romanha et al. (1982) typed T.cruzi isolates from 69 chronic chagasic patients, from the endemic region, of Bambui, in Southeast Brazil, into four groups, zymodemes; A, B, C and D. The same isolates were further typed according to the electrophoretic pattern obtained after digestion of their k-DNAs by restriction endonucleases, and grouped into schizodemes (Morel et al., 1980). The number of schizodemes was higher than that observed for zymodemes.

In the present work we determined the influence of prolonged serial passages of $T$. cruzi in mice on their isoenzyme and k-DNA patterns.

\section{Material and Methods}

\section{T. Cruzi strains}

The $T$. cruzi strains were isolated by hemoculture from patients in the chronic phase of Chagas' disease, from the endemic region of Bambui (Chiari et al., 1979). The isoenzyme and k-DNA classifications of the isolates were made previously by Romanha et al. (1982) and Gonçalves et al. (1984b) respectively. After classification, the isolates were cryopreserved in liquid nitrogen. Thirteen out of 69 strains belonging to four zymodemes were chosen randomly, thawed and transferred to LIT (Liver Infusion Tryptose) medium (Camargo, 1964). The distribution of the 13 strains according to the zymodeme is shown in Table 1 . The strains were established and large numbers grown in LIT medium at $28^{\circ} \mathrm{C}$. A $90 \mathrm{ml}$ culture containing approximately $2.5 \times 10^{7}$ parasites $/ \mathrm{ml}$ was washed and harvested by centrifugation. Pellets from 30 and $60 \mathrm{ml}$ cultures were kept at $-70^{\circ} \mathrm{C}$ until used for isoenzyme and $\mathrm{k}$ DNA determination, respectively. In order to obtain high percentages of infective trypomastigotes, flagellates from LIT medium were transferred to M-16 medium (Chiari et al., 1980). On the 6th day of culture in M-16, parasite suspensions containing $10^{7}$ metacyclic trypomastigotes of each strain were inoculated intraperitoneally and maintained in $\mathrm{C} 3 \mathrm{H}$ isogenic mice.

\section{T. cruzi maintenance in mice}

The strains presenting patent parasitemia in mice were maintained throughout successive blood passages by i.p. injections at regular intervals. According to the parasitemia peak of each strain the passage intervals ranged from 7 to 20 days. Mice with subpatent parasitemia were submitted to hemocultures. The positive hemocultures were inoculated into mice and the parasites then maintained by alternated mouse-hemoculture passages.

\section{Isolation of T. cruzi strains from mice}

After a period of maintenance in mice of approximately 18 months, the strains were isolated by hemoculture in LIT medium. Table 1 shows the kind of maintenance, the parasitemia type, and the number of passages to which each strain has been submitted. The positive hemocultures were established and bulk cultures grown in LIT medium. The parasite culture forms were harvested and washed 3 times by centrifugation, $2000 \times g, 4^{\circ} \mathrm{C}, 10 \mathrm{~min}$, in KRT (Krebs Ringer Tris, $\mathrm{pH} 7.3$ ) buffer. 
The parasite pellet was stored at $-70^{\circ} \mathrm{C}$ until used for isoenzyme and k-DNA pattern determination.

\section{The isoenzyme pattern}

The culture form pellet stored at $-70^{\circ} \mathrm{C}$ was thawed at room temperature and submitted to osmotic lysis in an enzyme stabilizer $(2.0 \mathrm{mM}$ dithiothreitol, $2.0 \mathrm{mM} \varepsilon$ aminocaproic acid and $2 \mathrm{mM} \mathrm{Na} \mathrm{Na}_{2}$-EDT, $\mathrm{pH} \mathrm{7.0)}$ at $4^{\circ} \mathrm{C}$, at the volume ratio 1:1. The lysate was centrifuged at $15000 \times g, 1 \mathrm{~h}$ at $4^{\circ} \mathrm{C}$. The supernatant, called enzymatic extract, was cryopreserved in liquid nitrogen as small drops of approx. 15 $\mu l$. The isoenzymes were separated by refrigerated horizontal thin-layer starch gel electrophoresis. The enzymes studied were: alanine aminotransferase (ALAT) [EC 2.6.1.2], asparate aminotransferase (ASAT) [EC 2.6.1.1], malic enzyme (ME) [EC 1.1.1.40], 6-phosphogluconate dehydrogenase (6PGD) [EC 1.1.1.44], phosphoglycomutase (PGM) [EC 2.7.5.1], glucose-6-phosphate dehydrogenase (G6PD) [EC 1.1.1.49], glucose phosphate isomerase (GPI) [EC 5.3.1.9] and malate dehydrogenase (MDH) [EC 1.1.1.37]. The staining system and electrical conditions for ALAT, ASAT, PGM and GPI were those of Romanha et al. (1979a), for G6PD and ME those of Miles et al. (1980). For 6PGD, the electrode buffer was $150 \mathrm{mM}$ Trismaleate, $\mathrm{pH} 7.4$, which was diluted ten times in water for the gel. Electrophoresis was carried out for $3 \mathrm{~h}$ at constant voltage, $20 \mathrm{~V} / \mathrm{cm}$. For $\mathrm{MDH}$, the electrode buffer was $75 \mathrm{mM}$ sodium citrate, $\mathrm{pH}$ 6.0, which was diluted ten times in water for the gel. Electrophoresis was carried out for $2.5 \mathrm{~h}$ at constant voltage, $25 \mathrm{~V} / \mathrm{cm}$. The staining solutions for both enzymes were as according to Harris and Hopkinson (1976).

\section{$k-D N A$ pattern}

The washed culture form pellet stored at $-70^{\circ} \mathrm{C}$ was thawed at room temperature and submitted to k-DNA extraction according to Gonçalves et al. (1984a). The kDNA was digested by the enzyme EcoRI and the fragments separated by vertical electrophoresis in acrylamide gel. The electrophoretic pattern was visualized by ethidium bromide flourescence (Gonçalves et al., 1984a).

\section{Results}

\section{Parasitemia}

Whatever the initial zymodeme of the $T$. cruzi strains, the parasitemia kept the same pattern after prolonged maintenance in mice. The only exception was the 222 strain which changed its parasitemia from subpatent to patent after eight passages in mice (Table 1).

\section{Isoenzyme patterns}

The isoenzyme pattern of 5 out of $13 T$. cruzi strains maintained in mice by serial blood passages for about 18 months changed when compared with their initial patterns. Isoenzyme pattern changes occurred at the same time in 6 out of 8 enzymes 
TABLE I

Parasitemia and zymodemes of Trypanosoma cruzi strains before and after maintenance in $\mathrm{C} 3 \mathrm{H}$ mice

\begin{tabular}{|c|c|c|c|c|c|c|}
\hline \multirow[t]{2}{*}{ Strain } & \multirow[t]{2}{*}{ Maintenance } & \multirow{2}{*}{$\begin{array}{l}\text { Passage } \\
\text { number }\end{array}$} & \multicolumn{2}{|c|}{ Parasitemia $^{a}$} & \multicolumn{2}{|c|}{ Zymodeme } \\
\hline & & & Initial & Final & Initial & Final \\
\hline 138 & Blood & 34 & $\mathrm{P}$ & $\mathrm{P}$ & $\mathrm{A}$ & A \\
\hline 229 & Blood & 44 & $\mathrm{P}$ & $\mathrm{P}$ & A & A \\
\hline 239 & Blood & 26 & $\mathrm{P}$ & $\mathrm{P}$ & A & A \\
\hline 84 & Blood & 11 & $\mathrm{P}$ & $\mathrm{P}$ & $\mathrm{AB}$ & $\mathrm{A}$ \\
\hline 144 & Blood & 27 & $\mathrm{P}$ & $P$ & $\mathbf{B}$ & B \\
\hline 147 & Blood & 48 & $\mathrm{P}$ & $\mathrm{P}$ & B & B \\
\hline 167 & Blood & 48 & $\mathrm{P}$ & $\mathrm{P}$ & $\mathbf{B}$ & A \\
\hline 182 & Alternate $^{\mathbf{b}}$ & 8 & $\mathbf{S}$ & $\mathrm{s}$ & $\mathrm{C}$ & B \\
\hline 222 & Alternate & 8 & $\mathrm{~S}$ & $\mathrm{P}$ & $\mathrm{C}$ & $\mathrm{C}$ \\
\hline $222 p$ & Blood & 9 & $\mathrm{P}$ & $\mathrm{P}$ & $\mathrm{C}$ & $\mathbf{B}$ \\
\hline 231 & Alternate & 3 & $\mathrm{~S}$ & $\mathrm{~S}$ & $\mathrm{C}$ & $\mathrm{C}$ \\
\hline 254 & Alternate & 3 & $S$ & $\mathrm{~S}$ & $\mathrm{C}$ & $\mathrm{C}$ \\
\hline 150 & Blood & 32 & $P$ & $\mathbf{P}$ & D & D \\
\hline 207 & Blood & 21 & $P$ & $\mathbf{P}$ & $\mathrm{D}$ & A \\
\hline
\end{tabular}

${ }^{\text {a Parasitemia: }} \mathbf{P}=$ patent and $\mathrm{S}=$ subpatent

${ }^{b}$ Alternate $=$ cyclic mouse-hemoculture passages.

studied. The three strains initially classified as zymodeme A remaining unchanged during this period (Table 1 and Fig. 1a). The strain 84 classified initially as mixed zymodeme $A B$ was clarified as zymodeme $A$ after this time of passage. The strains 144 and 147 (classified initially as zymodeme B) maintained the same zymodeme whereas strain 167, also classified as zymodeme B, changed to A (Figs. la and 2a). In order to detect the time the isoenzyme pattern may change, the 167 strain zymodeme was determined after each successive passage. For this particular strain the isoenzyme pattern changed from zymodeme $B$ to $A$ after the first passage in mice (results not shown).

Strains 222, 231 and 254, classified initially as zymodeme C, after being maintained in mice by alternate passages, showed the same initial zymodeme (Table 1 and Figs. $1 \mathrm{~b}$ and $2 \mathrm{~b}$ ). Strain 182 , after eight alternate passages, changed from zymodeme C to $B$. On the other hand, strain 222 , after eight alternate passages, kept the zymodeme unchanged but changed the parasitemia from subpatent to patent. Due to this parasitemia change, strain 222 (now called 222p), was maintained in mice thereafter by successive blood passages. Thus, after nine successive blood passages the parasites changed from zymodeme $\mathrm{C}$ to $\mathrm{B}$ (Table 1, Figs. 1b, 2b).

Strain 150 classified initially as zymodeme D, a mixture of zymodemes A and C, after being maintained 18 months in mice kept the same zymodeme whereas strain 207 changed its zymodeme from zymodeme D to A (Table 1, Figs. 1b, 2b).

\section{$k-D N A$ patterns}

Figs. 3 and 4 show the k-DNA patterns of $T$. cruzi strains before and after maintenance in mice. Except for 167, 182, 222p and 207, the other strains kept their 

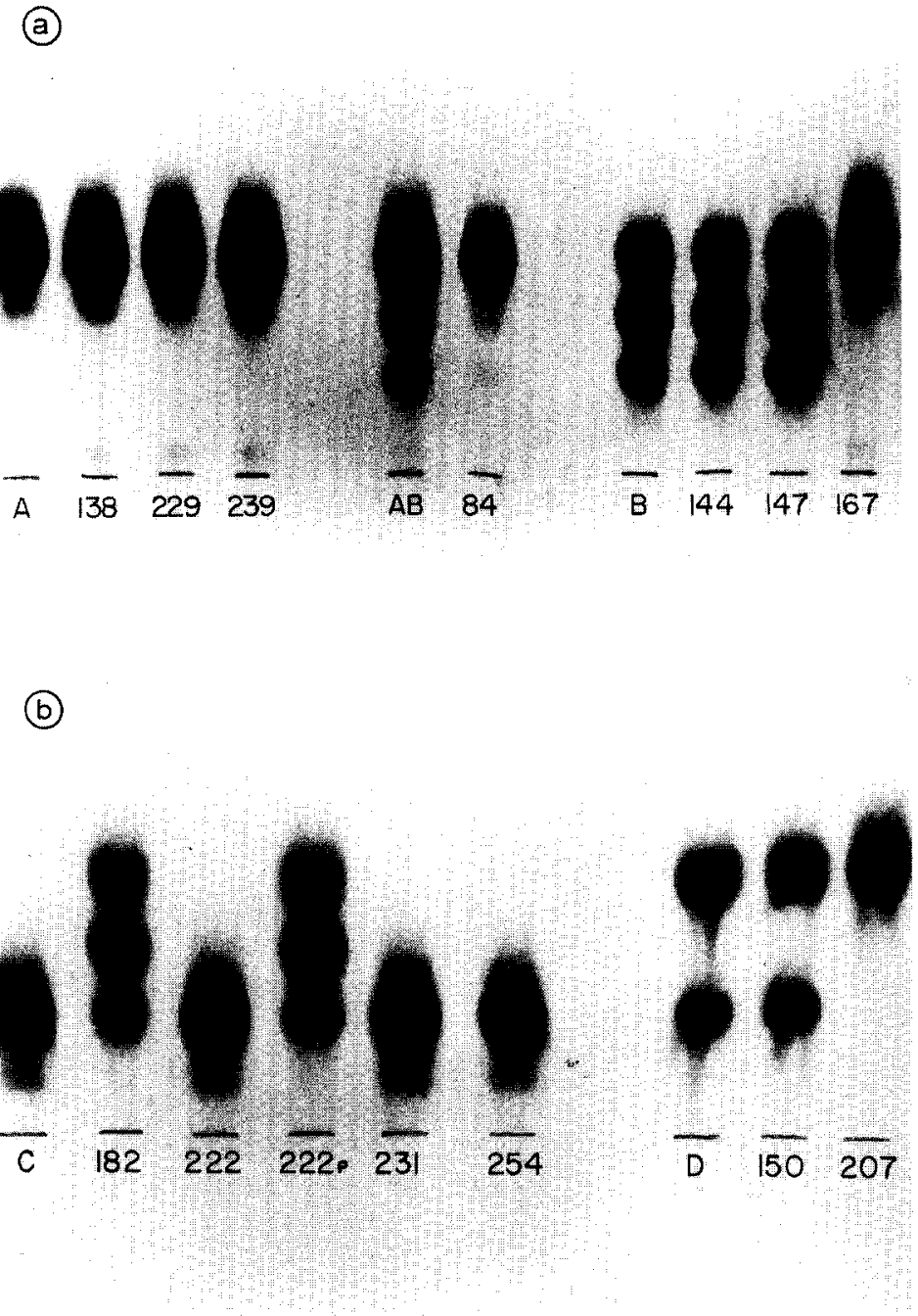

Fig. 1. GPI enzyme patterns of $T$. cruzi strains before and after maintenance in C3H mice: (a) T. cruzi strains from zymodemes A, AB and B; (b) T. cruzi strains from zymodemes C and D. A, AB, B, C and D are the patterns presented before mouse passage and the numbers the patterns presented by the coded strains after maintenance in mice.

k-DNA patterns constant. Since the initial k-DNA pattern of the 239 strain was not determined it is not possible to say whether it had changed or not after maintenance in mice. All k-DNA pattern changes were towards simpler patterns with less bands and better resolution. A typical example of this type of change is that of strain 207 which showed a final simple pattern resulting from the disappearance of a number of bands present in the more complex initial pattern. The final patterns were all different among the strains.

As with their isoenzyme patterns, strains 222,231 and 254 kept the same initial kDNA patterns (Fig. 4). Strain 182, after eight alternate passages, changed its k-DNA 

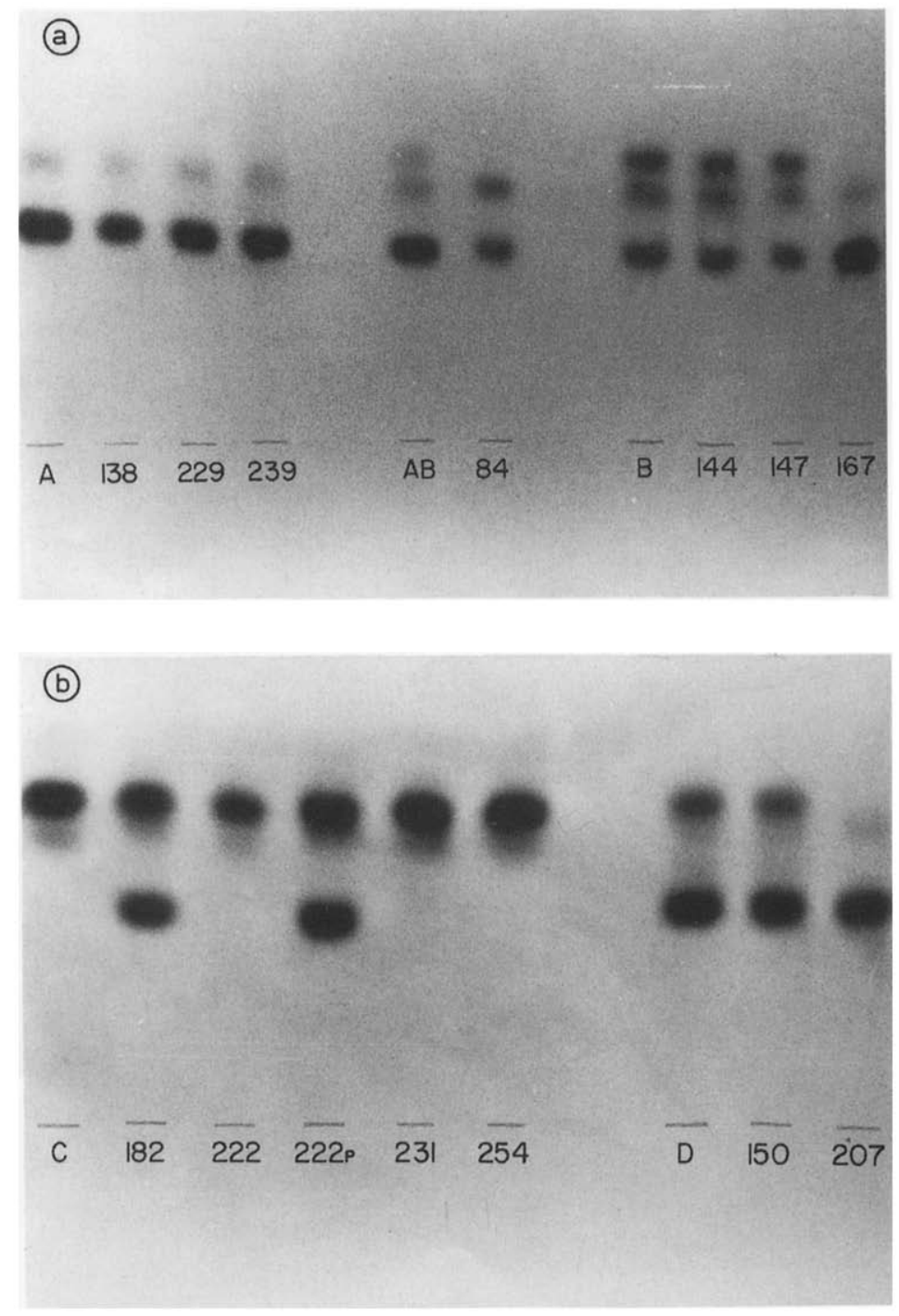

Fig. 2. PGM enzyme patterns of $T$. cruzi strains before and after maintenance in $\mathrm{C} 3 \mathrm{H}$ mice: (a) $T$. cruzi strains from zymodemes $\mathrm{A}, \mathrm{AB}$ and $\mathrm{B}$; (b) T. cruzi strains from zymodemes C and D. A, AB, B, C and D are the patterns presented before mouse passage and the numbers the patterns presented by the coded strains after maintenance in mice.

pattern without changing parasitemia. On the other hand, strain 222 after eight alternate passages kept the k-DNA pattern unchanged and changed the parasitemia (222p). Furthermore, after nine blood passages strain 222p also changed its k-DNA pattern (Table 1, Fig. 4).

Again like the isoenzyme pattern, strain $150 \mathrm{kept}$ the k-DNA pattern constant while strain 207 changed after maintenance in mice (Figs. 1b, 2b and 4). 

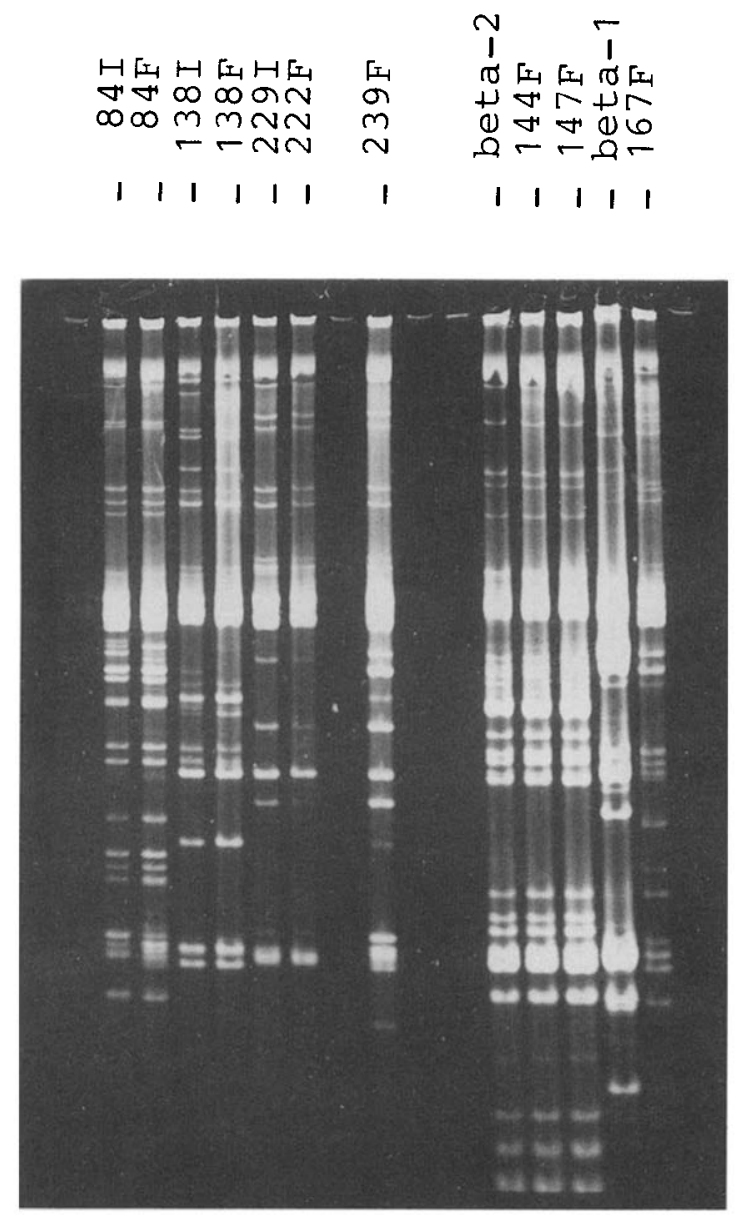

Fig. 3. k-DNA patterns of $T$. cruzi strains before and after maintenance in C3H mice. The k-DNA was previously digested by EcoRI restriction enzyme. $I, \beta-1$ and $\beta-2$ are the patterns presented before mouse passage and $F$ after mouse passage.

\section{Discussion}

The maintenance of $T$. cruzi strains in $\mathrm{C} 3 \mathrm{H}$ mice for 18 months changed the isoenzyme and k-DNA patterns of some strains. Five out of 13 strains had their zymodeme as well as schizodeme changed, and schizodeme changes occurred simultaneously with the zymodeme. Two different hypotheses can be considered to explain such changes: (1) the modification of the patterns observed are due to regulatory phenomena within a given genotype. In other words, the markers employed are not reliable as genetic markers and can be modified by environmental factors. Such a hypothesis was proposed by Mirelman (1987) to explain zymodeme changes in Entamoeba histolytica; (2) the markers are reliable genetic markers, and the changes are due to the fact that the original populations were in fact mixed stocks of two or more different genotypes. Some minor modifications would be accepted for a regulatory phenomena, but a total shift involving seven loci is hardly conceivable. 

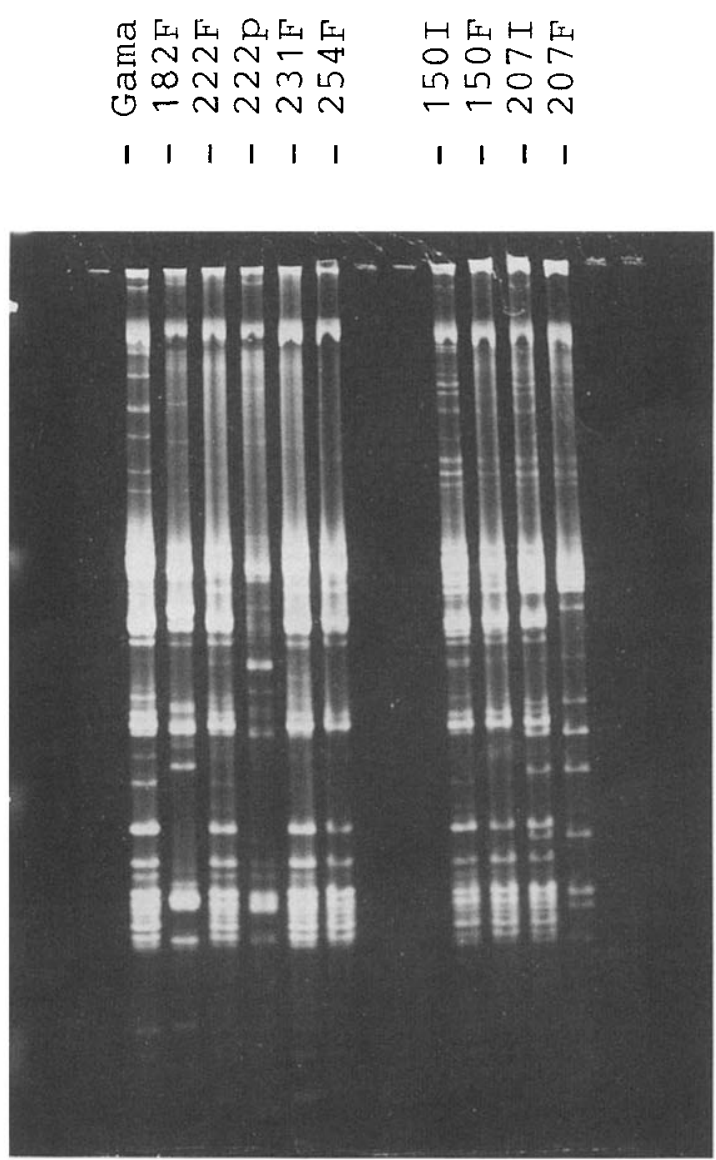

Fig. 4. k-DNA patterns of $T$. cruzi strains before and after maintenance in C3H mice. The k-DNA was previously digested by EcoRI restriction enzyme. $\gamma$ and I are the patterns presented before mouse passage and $F$ after maintenance in mice.

The fact that schizodeme changes were parallel to isoenzyme modifications strongly favors the second hypothesis. To confirm either hypothesis, clones should be obtained and the experimental protocol repeated with them. Only strain 84 changed its zymodeme without changing its schizodeme. This may be due to the fact that by the time the strain was in the $\mathrm{AB}$ zymodeme it had already changed its schizodeme. All changes were towards zymodeme A, suggesting that mice might select zymodeme A T. cruzi populations.

Lana et al. (1981) reported isoenzyme pattern stability for the T. cruzi Berenice strain during mouse passage. They also reported the isoenzyme stability of this strain isolated from a patient twice over a six year interval. Romanha (1982) showed that the maintenance of the $\mathrm{Y}$ and $\mathrm{CL}$ strains in exponential growth in liquid medium induced isoenzyme pattern changes towards zymodeme $C$. Taken together these data would suggest that zymodeme A strains develop, or are better adapted to, the vertebrate host while zymodeme $\mathrm{C}$ strains are better adapted to culture medium. Reinforcing this suggestion are the data from $T$. cruzi strains 84 and 207. They were initially mixtures of zymodemes $\mathrm{A}$ and $\mathrm{B}$ (zymodeme $\mathrm{AB}$ ), strain 84 , and $\mathrm{A}$ and $\mathrm{C}$ 
(zymodeme D), strain 207, and after maintenance in mice were characterized as zymodeme A. On the other hand, the permanence of mixed stocks represented by zymodeme D strain 150 , over 18 months of animal maintenance is an interesting result, suggesting that elimination or overdominance of one genotype by another is not a constant fact, and that two radically dissimilar genotypes can coexist for a long period of successive passages in mice.

The adaptation of strains from different zymodemes to mice is also suggested when parasitemia is considered. Strains from zymodeme A presented patent parasitemia while those from zymodeme $\mathrm{C}$ presented subpatent parasitemia. Since a continuous blood passage would put at risk the maintenance of subpatent parasitemia strains (zymodeme C) we alternated mouse infections with hemoculture. Strain selection in mice was also reported by Deane et al. (1984) who observed that the schedule of parasite inoculation and isolation favored the emergence of one or other strain when mice were double infected.

The better adaptation of zymodeme A $T$. cruzi strain to the vertebrate host is also suggested by the predominance of this zymodeme in isolates from chronic chagasic patients in Brazil. Romanha (1982) found 54\% of A zymodemes in chronic patients from Bambui city, Minas Gerais State, Brazil; Schlemper Jr. (1982) at Iguatama and Virgem da Lapa cities in the same State found $100 \%$ and Miles et al. (1981) in east and central and Luquetti et al. (1986) in a central region of Brazil found almost only zymodeme 2 (= zymodeme A) in chronic patients. In Bolivia, Tibayrenc and Desjaux (1983) and Tibayrenc et al. (1986) found that $T$. cruzi zymodeme predominance was more related to different areas and/or climatic factors than to a specific host.

A direct and immediate relationship between zymodeme changes and parasitemia had not been detected. Some strains changed their zymodeme without changing their parasitemia and vice-versa. However, strain 222 changed its zymodeme a few passages after its change in parasitemia, showing for this strain a direct but not immediate relationship. Since we did not follow the isoenzyme pattern of strain 222 after each murine passage we can not say precisely how many passages were needed for the zymodeme to become changed after the parasitemia had changed. What can be said is that at the end of nine successive blood passages the zymodeme had also changed (Table 1, Figs. 1b, 2b). Conversely, strain 182 showed zymodeme change without changing parasitemia. Strain 167 was the only one we followed to detect the passage the zymodeme and schizodeme would change. Zymodemes and schizodemes changed just after the first mouse passage, then kept constant thereafter up to the 48th passage when it was last classified. No parasitemia change was observed for this strain. On the other hand, strain 147, which had the same initial zymodeme as 167 and had also been passaged in mice the same number of times, did not change either its zymodeme or schizodeme.

Gonçalves et al. (1984b) showed that the k-DNA pattern divides $T$. cruzi strains in more groups than the isoenzymes at least for an isoenzyme range comparable to the one we used here. Therefore the 13 strains we studied were grouped into four zymodeme and nine schizodemes. Further, the strains from zymodeme B were divided into two schizodemes; $\beta-1$ and $\beta-2$. According to Carneiro et al. (1989), only the $\beta-2$ strains are lethal for $\mathrm{C} 3 \mathrm{H}$ mice suggesting a relationship between schizodeme and lethality. Conversely Sanchez et al. (1984) found no correlation between $T$. cruzi k-DNA minicircle structure and mice lethality.

The isoenzyme and k-DNA patterns have again been seen as good T. cruzi 
population markers and that mice, the most used experimental host, can selectively favor T. cruzi populations.

\section{Acknowledgments}

We are very grateful to Professor Z. Brener, Dr. Daniel G. Colley and Dr. M. Tibayrenc for critical reading and their suggestions for improving the manuscript, to Miss Maureen Rodarte for typing the manuscript, to Nedia S. Nehme for technical services and to UNDP/World Bank/WHO Special Programme for Research and Training in Tropical Diseases and Conselho Nacional de Desenvolvimento Científico e Tecnológico (CNPq)-Brazil for financial support.

\section{References}

Brener, Z. (1977) Intraspecific variations in Trypanosoma cruzi: two types of parasite populations presenting distinct characteristics. PAHO, Scientific Publication 347, 11-21.

Brener, Z. (1985) General review on Trypanosoma cruzi classification and taxonomy. Rev. Soc. Bras. Med. Trop. 18, 1-8.

Camargo, E.P. (1964) Growth and differentiation in Trypanosoma cruzi. I. Origin of metacyclic trypanosomes in liquid media. Rev. Inst. Med. Trop. São Paulo 6, 93-100.

Carneiro, M., Romanha, A.J. and Chiari, E. (1989) Caracterização biológica de cepas de Trypanosoma cruzi de diferentes zimodemas e esquizodemas. Mem. Inst. Oswaldo Cruz, submitted.

Chiari, E., Marques Araújo, S. and Carneiro, M. (1980) Meios empobrescidos em nutrientes na diferenciação epimastigota-tripomastigota do Trypanosoma cruzi. VII Reunião Anual sobre Pesquisa Básica em Doença de Chagas, Caxambú, MG.

Chiari, E., Dias, J.C.P., Lana, M. and Chiari, C.A. (1979) Hemocultures for the parasitological diagnosis of human Chagas disease in the chronic phase. Cong. Int. Doença de Chagas, Rio de Janeiro.

Deane, M.P., Souza, M.A., Pereira, N.M., Gonçalves, A.M. and Morel, C.M. (1984) Trypanosoma cruzi inoculation schedules and re-isolation methods select individual strains from doubly infected mice, as demonstrated by schizodeme and zymodeme analysis. J. Protozool. 31, 274-280.

Gonçalves, A.M., Nehme, N.S. and Morel, C.M. (1984a) Trypanosomatid characterization by schizodeme analysis. In: C.M. Morel (Ed.), Genes and Antigens of Parasites. A Laboratory Manual, 2nd edn., Fundação Oswaldo Cruz, Rio de Janeiro, pp. 95-109.

Gonçalves, A.M., Chiari, E., Deane, M.P., Carneiro, M., Romanha, A.J. and Morel, C.M. (1984b) Schizodeme characterization of natural and artificial populations of Trypanosoma cruzi as a tool in the study of Chagas disease. In: New Approaches to the Identification of Parasites and their Vectors. Proc. Int. Symp., World Health Organization, 8-10 November 1982, Geneva, pp. 253-275.

Harris, H. and Hopkinson, D.A. (1976) Handbook of enzyme electrophoresis in human genetics. North Holland, Amsterdam

Lana, M., Chiari, C.A., Chiari, E., Romanha, A.J. and Morel, C.M. (1981) Caracterização de forma de cultura do Trypanosoma cruzi isolada da paciente Berenice em diferentes períodos. VIII Reunião Anual sobre Pesquisa Básica em Doença de Chagas, Caxambú, MG.

Luquetti, A.O., Miles, M.A., Rassi, A., Rezende, J.M., Souza, A.A., Povoa, M.M. and Rodrigues, 1. (1986) Trypanosoma cruzi: zymodemes associated with acute and chronic Chagas' disease in central Brazil. Trans. R. Soc. Trop. Med. Hyg. 80, 462-470.

Miles, M.A., Lanham, S.M., Souza, A.A. and Povoa, M. (1980) Further enzymic characters of Trypanosoma cruzi and their evaluation for strain identification. Trans. R. Soc. Trop. Med. Hyg. 74, 221-237.

Miles, M.A., Povoa, M.M., Prata, A., Cedillos, R.A., Souza, A.A. and Macedo, V. (1981) Do radically dissimilar Trypanosoma cruzi strains (zymodemes) cause Venezuelan and Brazilian forms of Chagas' disease. Lancet 20, 1338-1340.

Mirelman, D. (1987) The pathogenicity of Entamoeba histolytica. Parasitol. Today 3, 37-40. 
Morel, C.M., Chiari, E., Camargo, E.P., Mattei, D.M., Romanha, A.J. and Simpson L. (1980) Strains and clones of Trypanosoma cruzi can be characterized by pattern of restriction endonuclease products of kinetoplast DNA minicircles. Proc. Natl. Acad. Sci. U.S.A. 77, 6810-6814.

Romanha, A.J. (1982) Heterogeneidade isoenzimática em Trypanosoma cruzi. Ph.D. Thesis, UFMG.

Romanha, A.J., Silva Pereira, A.A., Chiari, E. and Kilgour, V. (1979a) Isoenzyme patterns of cultured Trypanosoma cruzi: changes after prolonged subculture. Comp. Biochem. Physiol. 62B, 139-142.

Romanha, A.J., Silva Pereira, A.A., Chiari E. and Dias, J.C.P. (1979b) Isoenzyme patterns of Trypanosoma cruzi isolated from patients with Chagas' disease. Cong. Int. Doença de Chagas, Rio de Janeiro.

Sanchez, D.O., Frasch, A.C.C., Carrasco, A.E., Gonzalez-Cappa, S.M., De Isola, E.D. and Stoppani, A.O.M. (1984) Rapid evolution of kinetoplast DNA mini-circle subpopulations in Trypanosoma cruzi. Mol. Biochem. Parasitol. 11, 169-178.

Schlemper Jr., B.R. (1982) Caracterização de cepas do Trypanosoma cruzi isoladas de pacientes com diferentes formas clínicas da doença de Chagas. Ph.D. Thesis, UFRJ.

Tibayrenc, M. and Desjaux, P. (1983) The presence in Bolivia of two distinct zymodemes of Trypanosoma cruzi, circulating sympatrically in a domestic transmission cycle. Trans. R. Soc. Trop. Med. Hyg. 77, 73-75.

Tibayrenc, M. and Ayala, F.L. (1988) Isozyme variability in Trypanosoma cruzi the agent of Chagas' disease: genetical, taxonomical, and epidemiological significance. Evolution 42, 227-292.

Tibayrenc, M., Hoffman, A., Poch, O., Echalar, L., Le Pont, F., Lemesre, J.L., Desjauz, P. and Ayala, F.J. (1986) Additional data on Trypanosoma cruzi isozymic strains encountered in Bolivian domestic transmission cycles. Trans. R. Soc. Trop. Med. Hyg. 80, 442-447. 